\title{
Immanent Transcendent Angles on a Post-Reformation Theology
}

\author{
Cornel W. du Toit \\ Research Institute for Theology and Religion, University of South Africa, \\ P. O. Box 392, 0003 UNISA, Republic of South Africa \\ dtoitcw@unisa.ac.za
}

\begin{abstract}
The article offers examples of a post-Reformation theology which could be described as postmodern, post-metaphysical, anti-fundamentalist, immanent transcendent, corporeal, narrative, holistic and secularly spiritual. As examples of the kind of Reformed belief that is increasingly questioned it examines the doctrine of revelation, the doctrine of God and of salvation, with proposals of how they could be accommodated in an immanent transcendent model. Philosophy of consciousness (with reference to Hegel and Sartre) serves to clarify the transcendentally wired nature of human consciousness. The underlying question is how affect can be understood in a rational, epistemological framework. Human consciousness has to be linked to bodily functions, more especially emotions, to appreciate how religious experience occurs in a secular spiritual context. Narrative is spotlighted as the medium that is pre-eminently suited to convey a holistic concept of religious experience.
\end{abstract}

\section{Keywords}

post-Reformation theology, doctrine of revelation, doctrine of God, doctrine of sin, doctrine of salvation, bodily turn, immanent transcendence, secular spirituality, rationality, philosophy of consciousness, emotion, Sartre, Damasio

\section{Introduction: Why Have a Post-Reformation Theology?}

The article presents some critical comments on our thinking and talk about God in a post-Reformation, interdisciplinary context. By post-Reformation context I mean one in which the classical Reformed approach forms the background to the current debate. Just as postmodernism needs to be understood in light of modernism, so post-Reformation theology consists in critical glosses in a semper reformanda spirit. Naturally there is no such thing as "postReformation theology", all we have is a wide range of responses to Reformed theology. Some can be subsumed under generic terms like postmodern, post-metaphysical, anti-fundamentalist, immanent-transcendent, corporeal, 
narrative, holistic and secular-spiritual. Some aspects of the responses will be discussed below. I look at cornerstones of Reformed theology: the sola principle and hermeneutics, doctrine of God, the accent on the sin-redemptiongratitude triptych and how it could function in a postmodern culture, and the question of a hermeneutic focus complemented by human corporeality and specifically human emotion to secure a more holistic, interdisciplinary slant on religion.

So what I have to say about post-Reformation theology does not profess to be sensational or new: there is no need for it. After all, post-Reformation history did not end with the Reformers. They merely set the ball rolling. PostReformation theology is simply the outcome of an ongoing Reformed tradition in theology. In the course of history new questions arose that historically frozen dogma could not answer. Besides, it was a theology shaped by its particular historical era as a counterweight to a dominant viewpoint - mainly the Reformers' by now largely irrelevant struggle against the Roman Catholic Church. Post-Reformation theology, therefore, merely places existing, previously gained insight in a new perspective. The angles to be considered include epistemology, metaphysics, ontology, the sciences and the problem of interdisciplinary integration. Traditionally metaphysics has always made absolute claims. To claim that our thought is really free from metaphysics, fundamentalism, bias, subjectivity, even irrationality and superstition, is absolutist. It is historically contingent, culturally governed, biased in its intentionality, biologically determined, reactionary and all the rest. It is biased to devise a doctrine of God, a soteriology or any other dogma on an exclusive basis, be it revelation, metaphysics, language, epistemology, the self (philosophy of consciousness), nature, human biology or science. That means that all our talk about God, the world and ourselves is purely provisional. Human thought per se is perspectival, open and changeable. The underlying violence of metaphysics is the will to govern via absolutes. ${ }^{1}$ Indeed, violence is basic to all philosophical models that seek to govern. ${ }^{2}$

\footnotetext{
${ }^{1}$ Merold Westphal reminds us of F. H. Bradley's notion that "metaphysics is the finding of bad reasons for what we believe upon instinct", Merold Westphal, "Whose philosophy? Which religion? Reflections of reason as faith," in Transcendence in Philosophy and Religion (ed. James E. Faulconer; Bloomington: Indiana University Press, 2003), 17. It does not imply that instinct is right or wrong, but that we are probably governed by an instinctive will to find certainty.

${ }^{2}$ Heidegger formulated it in his reflection on worldview, Martin Heidegger, The Question Concerning Technology and Other Essays (New York: Harper \& Row, 2007), 128-136. A worldview is a picture we invent that suits us. It is $m y$ worldview, which assigns me, the determining subject, a position of control. The controlling subject could be the individual, the community, the nation or the state, 'modern' humans. My worldview is my picture of the world in which I stand confronted with that world (as my object). Hence, it is a picture of the human person
} 
Every age talks and thinks differently about God. A feature of our age is that more and more people are critical of the faith they grew up in, yet do not bid it farewell. Every age has its own religious décor. On the religious stage the actors are believers who enact their religious drama against a backdrop of décor that does not accord with contemporary existential trends. Can/should the décor be adjusted to the present-day religious text? But we are too accustomed and too attached to the décor to change it. ${ }^{3}$ Religious language is part of an other-worldly décor. We use traditional religious language to communicate contemporary thoughts. We use traditional images to express present-day needs and meanings. We believe, to be sure, but in our verbal confession of that faith creation, sin, salvation, time and eternity, life and death, theism are viewed differently. Yet we continue to cherish the pyramids of yesteryear. In the Western mind the cross is a towering mental pyramid, one of the wonders of the cultural world. It expresses the cultural impact of a particular value and will probably form part of the traditional Reformed view for a long time to come.

A post-Reformation approach calls for an incarnation of church doctrine and church proclamation into the contemporary life world. The mode of this incarnation is what I call immanent-transcendence, as explained below. The church's dogma has metaphysically put religion beyond the reach of our selfunderstanding and our understanding of the world we live in. From a postReformation angle, an absolutist approach to Scripture and faith exchanges the sola principle for an atque (both... and) principle. Atque scriptura, atque gratia and atque fidei recognise the importance of Scripture, faith and grace without turning them into historically absolute filters to censor all religious language and theology. That is because today the sola principle, the doctrines of revelation, grace and faith appear essentialist, exclusivist, metaphysical, a-contextual, reductive and anti-physicalist (or supernatural).

The biblical sciences, for instance, put the accent on structural analysis within a broader framework of structuralism. Yet structural analysis easily degenerates into structural essentialism. The structuralist emphasis should be seen against the background of realism, which assumes the existence of an

rather than of the world. That is how humanism arose when the world became a picture (a view).

${ }^{3}$ Caputo rightly points out that (in a Western/Christian context) we cannot understand ourselves except in biblical terms and images: "So to take away the Bible is to take away meaning. It would be like taking Dante away from the history of Italian literature. Dante, like Shakespeare, is written is such a way that, if you did not read the Bible you would not understand anything," John D. Caputo and Gianni Vattimo, After the Death of God (New York: Columbia University Press, 2007), 36. A more telling example, maybe, is the role of Christianity (the Bible) in the evolution of science and philosophy that has brought us where we are today. 
external world independent of the human mind that can nonetheless be known. Hence there is an underlying structure to reality and the purpose of science is to explain it. The structure of a text can be established scientifically, which gives us an interpretive grasp of that text. Originally the interpretive task was delegated hermeneutically to the human sciences, whereas the physical sciences put the emphasis on explanation. Structuralism endeavoured to admit the textual sciences to the "scientific" stage.

Following the physical sciences, the "hermeneutic sciences" developed the idea of critical realism and, like the physical sciences, incorporated the possibility of falsification into their methodology. ${ }^{4}$ But positivism and hermeneutics may be seen as mirror images of each other, with the accent on empiricism and individualism. Nonetheless critical realism opens up the closed metaphysic circle to prospects of new perspectives and interpretations. This is in line with the Hegelian principle, according to which the negative becomes an instrument of perpetual self-correction in the ongoing development of knowledge. This self-correcting facet of research also accentuates the historically contingent and culturally determined nature of the whole enterprise, which in its turn curbs claims to universal 'truth'.

Criticism of foundationalism does not entail scepticism or relativism as an alternative, but emphasises self-correcting falsification. Post-structuralism (see especially the work of Roland Barthes) forms the background to deconstruction, propagated mainly by Derrida. The so-called linguistic turn and the accent on the end of subjective philosophy should be viewed in the same light. ${ }^{5}$ Postmodernism has no autonomous, bold, active self in whom God is internalised. ${ }^{6}$ The decentred subject is swept along in a movement that curtails all absolute autonomy.

The idea that philosophy has brought the end of the subject should not be taken too literally. We may have reached the end of a particular perception of the subject, but new scientific developments open up new angles on old

\footnotetext{
${ }^{4}$ See Roy Bhaskar's A Realist Theory of Science (Sussex: Harvester Press, 1978). See also Gerard Delanthy and Piet Strydom, eds., Philosophies of Social Science (Philadelphia: Open University Press, 2003), 381.

${ }^{5}$ From Greek antiquity to the Middles Ages objective knowledge was thought possible. Descartes changed this tradition by highlighting the subject that can only be sure of its own inner world. Knowledge is knowledge of one's own consciousness. Kant, whilst recognising both the inner world and external reality, introduced the dualism of a noumenal and a phenomenal world. Hegel overcame the dualism with his dialectics that links subject and object, inner and external world. Sartre took this further in his work (to be discussed below), but neglected the biological confinement of mind. The philosophy of the subject is bound to resurface in light of developments in the cognitive sciences. The challenge is to relate it to the philosophy of consciousness.

${ }^{6}$ Anthony Thiselton, Interpreting God and the Postmodern Self (Edinburgh: T\&T Clark, 1995), 85.
} 
conundrums. They include the impact of the new cosmology and new physics and the influence of the cognitive and brain sciences. We live in the era of what I would call the bodily turn, in which new insights help us to understand the bodily, biological roots of mind, language and cognition in new ways. This has a ripple effect, triggering reflection on spirituality in a post-secularisation, techno-scientific context, which has implications for our present-day understanding of God.

\section{The Doctrine of God in Immanent Transcendent Perspective}

The boundaries of transcendence have shifted. To many people the transcendent is no longer a supernatural or otherworldly realm but part of immanent, everyday reality - part of the human order. Transcendence in the sense of a movement towards some other reality, the dawn of the unexpected and the unforeseeable, is a hallmark of human experience of space and time, of human language and consciousness, of human self-experience and history. God is not encountered in the mode of radical transcendence, but through the medium of kenotic incarnation he always incarnates transcendence, thus opening the door to what is different. Incarnation incarnates transcendence, which opens up a window on the astounding. Transcendence is experienced in the human mind, self-image, other people, the future, nature, day-to-day affairs. God's radically transcendent revelation is not a disclosure (apocalypse) of the divine but an unmasking of the human person. Self-unmasking is simply selfunderstanding, usually experienced as a result of an event in which we discern a transcendent dimension. Self-understanding is an ongoing process, because the human self, like God, can never be (finally) known.

But transcendence is not restricted to the religio-spiritual dimension. The human mind is wired for transcendence. So are our language, texts, our experience of time and space, the operation of human imagination and fantasy. They move from one concept or idea to the next, each time coming up with a new meaning. Our transcendentally wired brains function metaphorically by discovering patterns (meaning) where none existed before. Patterns, meaning, structure are metaphorically ascribed to the world so it can make sense to us. Human thought is always a movement of the will to meaning. Chance events are incorporated into our life story by discerning a pattern in them, assigning them another dimension, a personal colour. We transcend the ostensible interpretation of our own and other people's actions and probe their intention.

We transcend events by discerning a transcendent, personal power or will behind them. This power is assigned a particular intention, either good or evil. Impersonal chance is given a face and a history, so random good luck ceases to 
exist; an unknown person's helping hand becomes God's providential intervention. Viewed objectively, attributing transcendence to chance events may appear naïve, superstitious, even irrational. But to people that is what adds dimension and colour to their lives. In the process human emotion and affect play a crucial role. The physical cosmos arose from the information potentially built into it, and it evolved according to laws under the influence of time and the role of chance. The cosmos and evolution on our planet proceed blindly, with no blueprint or teleology, purely through the interplay of chance and laws. But humans assign their lives a blueprint and teleology. That was just the way we evolved. This is why religion fits us like a glove.

Traditionally God-talk took place in the mode of metaphysical infinitude or of apophatic (negative) theology. ${ }^{7}$ God cannot be known or domesticated. He is like the sun, which you cannot look at but by whose light you see everything. That is why God-talk is talk about ourselves, lighting our world. Sunlight doesn't change, but the world on which it shines is never the same, neither is our self-understanding. To take an image from thermo-dynamics (the second law of enthropy), it is the very dwindling of solar energy that leads to evolution, increased complexity of life and culture on earth. Religious language evolves in tandem with human culture and self-understanding.

In traditional Reformed terms God speaks first and humans are expected to respond. God speaks through revelation and humans must respond in reverent obedience. Underlying this belief is a fear that God-talk may consist in humanly initiated ideas that add something to his revelation. There is a sobering reluctance to speak about God as theologians used to do, as if they knew exactly who and what he is, wills and does. God-talk is paradoxical: how can you talk about something you cannot know? Revelational language is human language that camouflages God in metaphor, paradox and cultural idiom. Dogma is coloured by the culture and philosophy of the age; biblical stories and history have extra-biblical stories as their meta-text. The stories and ideas incorporated into revelation already contain elements that will inexorably evoke new ideas and responses from each new era: "Christianity is a stimulus, a message that sets in motion a tradition of thought that will eventually realize its freedom from metaphysics". ${ }^{8}$ That is an anti-foundationalist approach. Knowledge is not ontologically sub specie aeternitatis. Not even scientific knowledge is foundational, for it is open to falsification.

\footnotetext{
7 Negative theology should not be confused with the role of the negative in, for example, Hegelian thought. There the negative functions as a dialectical force resulting in self-correction and insight.

${ }^{8}$ Gianni Vattimo in Caputo and Vattimo, After the Death of God, 35.
} 


\section{The Classical Sin-Redemption-Gratitude Schema in an Immanent Transcendent Context}

The classical Reformed trichotomy of sin-redemption-gratitude is an outdated metaphysical ontology, which could be reinterpreted today as desire-eventfulfilment. The sin-redemption-gratitude correlation bullies us into accepting a metaphysical schema, in which our natural fear of death is used to impose the assumption of our no less metaphysical sinfulness, so that we will embrace the no less metaphysical business transaction of the crucifixion. ${ }^{9}$ According to classical doctrine you are doomed by (original) sin as your fate, with death as the outcome. Instead of this amor fati we should rather have an amor venturi - love of the event. The traditional interpretation of the crucifixion may well be the source of the theodicy problem (what is the source of evil?). If God deems it necessary to have Jesus die on the cross in order to demonstrate his (God's) love, is he not also the one who, for whatever reason, permits evil and wretchedness? It makes God dependent on evil (the devil) and forces him to act 'inhumanly' (to compensate the devil, to whom we would otherwise have belonged, or for God's honour that was violated by human sin). Sacrifice is primitive. ${ }^{10}$ The crucifixion is supposed to evoke protest against human intolerance of anything different. Jesus was executed because of differences of opinion among people. God does not come to us via the crucifixion. Indeed, that is where he is not, just as he is not where evil flourishes. God came in the acts of love that Jesus is said to have performed. Atonement must not put the accent on damning fate but should stress the potential that life offers. PostReformation religion is not hamartio-centric. Take my sinfulness away and you take away my humanity. ${ }^{11}$ Take away human desire and you destroy the human will. Take away human responsibility and you destroy all morality.

9 See C. W. du Toit, "An Immanent Approach to Death: Theological Implications of a Secular View," HTS 65, no. 3 (2009): 484-491.

${ }^{10}$ For criticism of the notion of sacrifice, see Slavoj Žižek, The Puppet and the Dwarf. The Perverse Core of Christianity (Cambridge: MIT Press, 2003), 49-51; 53-57; 85-89; for his commentary on the Easter event, see 101; for an anthropological view of sacrifice, see René Girard, Things Hidden Since the Foundation of the World. London: Athlone, 1987).

11 Elemér Hankiss, The Toothpaste of Immortality. Self-constructing in the Consumer Age (Baltimore: Johns Hopkins University Press, 2006), 188, describes the modern deviation from the traditional concept of sin as follows: "Sin is considered a kind of illness, a distortion, and a guilty conscience is simply a neurosis. 'Lately I've been feeling guilty about my guilty feelings,' says Ziggy, the cartoon character, echoing the dilemma of millions of contemporary people”. Hankiss (187) defines the new values versus traditional ones thus (the traditional value appearing first): "Love thy neighbor!/Love thyself!; Sacrifice yourself!/Actualize yourself!; Discipline yourself!/ Enjoy yourself!; Your are guilty. Repent!/You are innocent!; Save! Be thrifty/Consume!; Live in a world of scarcity! /Live in a world of abundance; Obey! Conform!/Be free and autonomous; Be 
The sin-redemption scheme defers human fulfilment till after death. I believe so I can go to heaven. Faith becomes a fetish when it degenerates to faith in my faith. But faith is hollow if there are no meaningful experiences to give it a concrete, interactive history. The metaphysical schema freezes humans in their status as sinners and makes them reliant on no less metaphysical schemas of deliverance that will only be realised hereafter. The schema of desireevent-fulfilment (human flourishing) falls back on the universally human trait of desire, the openness to the coming of life/God/deliverance as events and the experience of fulfilment it entails. ${ }^{12}$ The desire-event-fulfilment schema replaces sin with desire, desire being the human experience of the endless movement towards life's possibilities; event instead of redemption stresses the possibility of encountering meaning fraught with transcendence in whatever medium it manifests itself (including the crucifixion); and the accent on fulfilment (human flourishing) highlights that we flourish in interpersonal relationships in which we permit others to flourish as well. It includes the dimension of gratitude, but not as a burden!

Sin looks backwards. It reduces life to accomplished actions. It fixes human identity as negative. It objectifies humans in certain acts (i.e. Hegel and Sartre's view of in-itself, in-sich, en-soi as opposed to the openness of for-itself, für sich, pour-soi). Desire, by contrast, looks to the future. Desire is a metaphor for life itself. It is infinite, indeterminate, the driving force of life and the alluring (tantalising) future. Human consciousness is wired for desire, which relates to the freedom of human existence. Human desire is a movement that is not arrested by the fulfilment of some need. But, unlike sin, it is not purely negative: it can also be positive. It is like freedom. Freedom entails choice and the wrong choice may lead to failure.

Redemption is always an event, not metaphysically once and for all, but typical of the course of life. It is a meaningful experience to which I append a personal dimension. In Christian symbolism it may be linked with the Easter events, but it cannot be confined to that. ${ }^{13}$

modest!/Be successful!; Punish yourself!/Spoil yourself!; Do your duty!/Fight for your rights!; Take care!/Take a risk!.”

${ }^{12}$ Replacing sin with desire does not mean that humans are sinless or impenitent. Desire stresses lack of fulfilment and a search for and experience of fulfilment in possible meaningful events and opportunities to flourish.

${ }^{13}$ In church history the Easter events have been swathed in a metaphysical onto-theology as embodied in Anselm's Cur deus homo? In this regard Caputo, in Caputo and Vattimo, After the Death of God, 66, writes: "It is a mystification to think that there is some celestial transaction going on here, some settling of accounts between the divinity and humanity, as if death is the amortization of a debt of longstanding and staggering dimensions." Caputo (2007:75) associates salvation with happenings here and now: "...they are no longer tales told about transcendent 
Fulfilment, replacing gratitude, concerns human happiness (Charles Taylor's notion of human flourishing), ${ }^{14}$ represented by the emotion of happiness. I am happy when I experience bodily and emotional equilibrium and I feel I am flourishing. But happiness is a process rather than a state and, like most emotions, it rarely lasts long. It is complemented by the infinitude of desire that forever drives the self to seek new happiness, to find new meaning. It is the antithesis of the manufactured happiness of consumer society, in which we are always sending each other off with the injunction: "Enjoy!"

\section{The Immanent Transcendent Wiring of the Human Mind: The Example of Sartre's Philosophy of Consciousness}

Immanent transcendence is wired into human consciousness. Consciousness is immanent. My primary experience of immanence is my consciousness of myself and of myself as a conscious self. But the true nature of consciousness lies in its movement, the endless flow of thought (Bergson's idea of the life stream). That is the foundation of transcendence. Consciousness is ever moving from one object to another, which at once invokes the negative. The negative, that which is contrary, different or alternative is the foundation of consciousness.

My premise is that body, mind and emotion influence each other. Change at one level has an impact on the other level. That means that separation of mind (thought) and body (which includes affect) leads to one-sided emphases. Epistemologically speaking there is no way of incorporating human affect into our rational activities, hence human rationality is one-sided. Ironically, David Ferrier coined the term 'epistemology' in the late 19th century to denote the systematic study of the question, how do we know? He was interested in the relation between mind and brain (what we now call cognitive science), so his aim was in fact to conjoin mind and body, ideas and empirical reality. ${ }^{15}$ The challenge is to combine knowledge of self, consciousness, physical and brain

transactions in eternity but stories about the saeculum, the historical time in which people live." In the same vein Fredriek Depoortere, Christ in Postmodern Philosophy. Gianni Vattimo, René Girard and Slavoj Žižek (New York: T\&T Clark, 2008), 98, criticises both Anselm's model and that of Abélard (namely that God sent his Son to die to arouse affect and thus bring about faith).

${ }^{14}$ C. Taylor, "Self-interpreting Animals," in Martin Heidegger (ed. Stephen Mulhall; Oxford: Ashgate, 2006), 55-86.

15 Steve Fuller, "The Project of Social Epistemology and the Elusive Problem of Knowledge in Contemporary Society," in Philosophy of Social Science (eds. Gerard Delanthy and Piet Strydom; Philadelphia: Open University Press, 2002), 429. 
processes with empirical knowledge and rational mental activity. So far we have failed to do so, probably because the processes governing the interaction between mind and body are too complex and we cannot pinpoint their exact relationship. When we explore the possibilities of such an enterprise we cannot disregard the phenomenology of consciousness (Husserl) and the philosophy of consciousness (Hegel, Sartre). These have to be linked with the findings of the cognitive and brain sciences. What follows is a cursory exploration of some ideas that may be pertinent to such an exercise (the bodily turn).

Philosophically the question of how we know can be traced back to the basic distinction between knowing subject and known object (noemanoemata). Indeed, that is the fundamental theme of all philosophy. The premise is human consciousness that is aware of something (external empirical objects, the self as object, ideas and thoughts as objects) and their relation to the self. We briefly consider some aspects of Sartre's philosophy of consciousness, since it is a relevant background to any reflection on the role of human affect and to form an integrated picture of mind and body when we probe present-day theological challenges (the integration of corporeality and faith). Sartre's magnum opus, Being and Nothingness (L'Etre et l'néant, 1943) remains directive, not only for its contribution to the phenomenology of consciousness, but for fathoming the concept of self in general.

Humans live in the world in the mode of conscious corporeality. Sartre sees the human body as the subject of consciousness: all consciousness is selfconscious. Consciousness of things in the outside world includes selfconsciousness, since it is I who am aware of these extraneous things. I am aware of my own state of mind and of extraneous objects. Sartre distinguishes between a reflective and a pre-reflective level of consciousness. At the prereflective level the self is simply conscious of the world, and consciousness is conscious of itself as consciousness of the world. ${ }^{16}$ Consciousness is always conscious of something, hence intentionally directed. Being aware of something (an object) is positional consciousness, which is pre-reflective, hence directed to something other than the self. But I can also focus on my own consciousness and make myself the object of reflection. That is reflective consciousness, consciousness reflecting on itself. ${ }^{17}$ That means being conscious of myself as an object, hence consciousness of myself as conscious of myself as an object. ${ }^{18}$

\footnotetext{
${ }^{16}$ Kathleen V. Wider, The Bodily Nature of Consciousness. Sartre and Contemporary Philosophy of Mind (Ithaca: Cornell University Press, 1997), 16.

${ }_{17}$ Wider, The Bodily Nature of Consciousness, 41.

${ }_{18}$ Wider, The Bodily Nature of Consciousness, 45.
} 
The distinction between in-itself and for-itself (en-soi and pour-soi) is basic to Sartre's work. ${ }^{19}$ In-itself is the law of identity, according to which every object equals itself $(A=A)$. For-itself, on the other hand, is not self-identity. But this $(A=A)$ does not apply to consciousness, for consciousness is freedom, desire, lack, possibility and the source of temporality, spatiality and movement. Consciousness is the source of the world and its attributes. ${ }^{20}$ The nature of consciousness that does not coincide with itself is what marks consciousness for-itself. ${ }^{21}$ Consciousness does not equal consciousness (as in-itself/A=A), for consciousness is self-consciousness $(\mathrm{A}=\mathrm{B})$. Self-consciousness must have an object in order to exist (hence for-itself). ${ }^{22}$ As the title of his magnum opus, Being and Nothingness, suggests, Sartre's main concern is the role of nothingness or the negative in our mental processes and our self-perception. ${ }^{23}$ Humans are inquiring beings. Directing a question to reality (being) implies that the answer could be negative, which includes the possibility of nothingness. Humans alone are their freedom - indeed, they must be if they are to ask questions and thus make nothingness part of being (reality). Nothing is always the

\footnotetext{
${ }^{19}$ In the context of this article this distinction must be related to the emphasis on human openness (desire) to what lies ahead, hence human infinitude. In the context of human consciousness the $e n-s o i$ is connected with the notion of transcendence as a recurring event, with the generative power of the negative and nothingness (including sin); with an anti-metaphysical, anti-reductive and post-fundamentalist attitude.

${ }^{20}$ Wider, The Bodily Nature of Consciousness, 43.

${ }^{21}$ He defines consciousness from the perspective of the for-itself as follows: "The for-itself is a being such that in its being, its being is in question is so far as this being is essentially a certain way of not being a being which it posits simultaneously as other that itself", Wider, The Bodily Nature of Consciousness, 174 . That simply means that I mentally make myself an object, that I may differ from the object but still know that the object is me. That is the paradox of selfconsciousness that makes the self an object, for the object is also the subject. Hence he adds a rider to the definition: "This means that the for-itself can be only in the mode of a reflection (reflett) causing itself to be reflected as not being a certain being", Wider, The Bodily Nature of Consciousness, 174. It also implies that I am more/other than myself whom I've made an object, for I am open, always different, for ever changing.

${ }^{22}$ Georg Wilhelm Friedrich Hegel, Encyclopedia of Philosophy (trans. G. E. Mueller; New York: Philosophical Library, 1959), 90, already posited that thought is always about something: "The principle is a content somehow determined - water, the One, nous, idea, substance, monad, and so forth; or, where it relates to the nature of cognition - like thought, intuition, sensation, ego, or subjectivity itself - it still begins with content." Consciousness (immediate being) is consciousness of some content or other: "immediate being is thus also the thought of immediacy..." (99).

${ }^{23}$ Chapter 1 of Jean-Paul Sartre, Being and Nothingness. An Essay on Phenomenological Ontol$o g y$ (London: Methuen, 1977), 3-45, is on the origin of nothingness. He explains: "The permanent possibility of non-being, outside us and within, conditions our questions about being. Furthermore, it is non-being which is going to limit the reply. What being will be must of necessity arise on the basis of what it is not" (5).
} 
flipside of being (reality). ${ }^{24}$ The negative, nothingness is essential for identifying difference and change. $\mathrm{A}=\mathrm{A}$ is perfect identity - Sartre's en-soi. As soon as there is difference, growth or change A no longer equals A. ${ }^{25}$ Thus transcendence always contains a negative element. Nothingness does not derive from the $e n$-soi, for that is positive. It must derive from being like humans who are their own nothingness. ${ }^{26}$

Nothingness is experienced intensely by the pour-soi when one considers past and future. I am my past and my future in the mode of not being either of them. Hence the law of identity does not apply to the pour-soi. ${ }^{27}$ "The foritself lacks being because as consciousness it is self-consciousness and thus cannot achieve the identity with self that characterizes being-in-itself”. ${ }^{28}$

Consciousness requires bodily data in the sense of data on the self and the world in which one lives. ${ }^{29}$ This input of body and world is constantly updated and jointly influence consciousness. But because it is continually changing, earlier data are in a sense negated: "The blending of input from both self and world means that consciousness of the object of awareness just is, in a sense, consciousness of oneself. Because of the constant updating and reprocessing of such input, the for-itself is continually nihilating and withdrawing from itself in withdrawing from and nihilating its object of awareness". ${ }^{30}$ Consciousness relies on memory in order to operate, so it is both one with and separate from the past. ${ }^{31}$

${ }^{24}$ Compare with the question of Parmenides: "Why is there something and not nothing?" Hegel developed the role of the negative in his Logic and Phenomenology of Spirit.

25 "A is identical with A only in abstraction from movement. It cannot state itself without a non-identical difference... Negation thus posits what it excludes. The Absolute differentiates itself and mediates itself to itself through its own negativity", Georg Wilhelm Friedrich Hegel, The Consummate Religion (Vol. 3 of Lectures on the Philosophy of Religion; Berkeley: University of California Press, 1985), 118.

26 Wider, The Bodily Nature of Consciousness, 48.

27 Wider, The Bodily Nature of Consciousness, 49.

${ }_{28}$ Wider, The Bodily Nature of Consciousness, 69.

29 Wider, The Bodily Nature of Consciousness, 143.

${ }^{30}$ Wider, The Bodily Nature of Consciousness, 151. Hankiss, The Toothpaste of Immortality, 240, reminds us of W. H. Auden's response to the Socratic comment that an unexamined life is not worth living: "the life too closely examined could not be lived at all".

${ }^{31}$ For lack of space I cannot probe Sartre's ideas in depth. The following comment must suffice. Whereas Hegel uses negativity productively to describe the development of the human mind, Sartre sees it as nothingness. It becomes instrumental in his existentialism, which doom us to freedom and the inevitability of wrong choices. This must be seen against the background of the aftermath to World War II. Secular spirituality also stresses human existence, contingence and openness but without undue emphasis. Human existence with all its inherent negativity in fact has a potential for meaningful events in which I can encounter the transcendent and achieve human flourishing. 
Proust said: "We remember the present while reliving the past". ${ }^{32}$ If I don't remember the eternal now in which I live, therefore, I will not have a past to live in. Complete self-knowledge would presuppose full recollection of oneself, which is manifestly impossible. That helps us to understand the dynamic, self-transcendent nature of human consciousness.

Now is a passing moment, over as soon as it happens. To grasp all the serial nows that make up my life I fall back on memory. It would therefore be more correct to say that we live virtually in our memories rather now (in reality)! Ontologically that makes the contents of the mind purely virtual. It makes time, my time, virtual. Like space and time, time and memory go hand in hand. Now is almost too fleeting to experience it. My time only becomes real in my memory when I reflect on it and retrospectively experience its events. Because I live in my memory, I do not have only the self of the past few minutes or hour in mind but can reflect on the self of last week or last year. I can no longer remember the exact hour or day, I only recall the event. We only remember remarkable events and the exact time (and circumstances) of their happening. When I think about myself purely as an event, act, relationship with someone, I objectify myself and my action or experience. This is where human affect comes into it: my memory is affectively coloured. ${ }^{33}$ When I think about certain events I am nostalgic, sad, embarrassed, scared, enraged all over again. So what constitutes our memory of ourselves and others is really just the much spurned emotion, the same emotion that we deny a place in our rationality. Yet my basic feeling about myself (and others) is co-determined by my emotional memory. It co-determines my intuition, perceptions, my very way of thinking about things. That is what we turn to now.

\section{Human Corporeality, Faith and Reason: A Reappraisal of Affect in an Integrated, Holistic Religious Perspective ${ }^{34}$}

The basic dichotomy between faith and reason (Jerusalem and Athens), ${ }^{35}$ mythos and logos, positivism and idealism may be traceable to the distinction

\footnotetext{
${ }^{32}$ Louis Dupré, Transcendent Selfhood. The Loss and Rediscovery of Inner Life (New York: Seabury, 1976), 72.

33 That probably accounts for dèja vu experiences and why Christmas, birthdays, certain places like a lecture room or church building always have a specific atmosphere for us.

${ }^{34}$ What follows must be read in light of the integrated perception of the body in postReformation theology.

35 The faith-rationality distinction (Jerusalem-Athens) is no alibi to exempt faith from the epistemological forum of rational inquiry. Faith is epistemologically accommodated in the sense that your basic premise may be a religious one, but the actual development of that premise is subject to logical/rational criteria.
} 
between what is and what is not empirically provable, between immanent and transcendent, natural and supernatural, rational and emotional. ${ }^{36}$ In all these distinctions the relation between rationality and affect is pertinent (affect is particularly pertinent to faith, mythos, idealism, the supernatural, and the transcendent). Rationality and affect are both grounded in human biology. Although rationality is always conveyed affectively, some facts are emotionally 'neutral' whereas others are profoundly moving. I sympathise when misfortune strikes a stranger, but my life is turned upside down when it happens to a loved one. That is the gist of Augustine's dictum that one only truly knows that which one loves. Faith usually concerns things that affect us profoundly, which is why we are partial to religious contents and symbols as vehicles of profound personal emotions. It seems to be typical of human nature to assign a privileged position to things that affect one deeply (res tua agitur). As a rule that privileged position has transcendent features that exempt it from immanent banality. Religious symbols and language, rites and ritual afford space to accommodate affect, which elsewhere is left to the mercy of rational judgment that may well make the emotional aspect appear irrational, naïve and embarrassing.

The biological ground of rationality and affect may help us to fathom the relation between them. In his criticism of Sartre's philosophy of consciousness Wider rightly points out that it does not really take account of the bodily roots of consciousness. ${ }^{37}$ As a result of the insights of the new brain sciences that relation is clearer than it was in Sartre's day. We base our discussion on the work of Antonio Damasio.

At a basic level, emotions are reduced to a dichotomy of those that are conducive to the organism's well-being (human flourishing) and those that are harmful or cause an imbalance (anything threatening or distressing). Damasio distinguishes between human flourishing and human distress. ${ }^{38} \mathrm{~A}$ lot has been written about animal emotionality. The history of evolution shows that emotionality came from the evolution of species. Organisms develop to become mobile. "The mobile ones needed the sensations they had: hunger, thirst, and hurt - painful sensations - but they also experienced pleasurable ones like satiety and coolness and warmth. They even had interests, the decrease of pain and the increase of pleasure". ${ }^{39}$ The development of sex by many bird species and mammals entailed the parallel development of parental nurture. Although

${ }^{36}$ That is the background to Gould's notion of NOMA (non-overlapping magistrata).

37 Wider, The Bodily Nature of Consciousness, $115 \mathrm{ff}$.

${ }^{38}$ Antonio Damasio, Looking for Spinoza. Joy, Sorrow and the Feeling Brain (Orlando: Harcourt, 2003), 6.

${ }^{39}$ P. A. Williams, "How Evil Entered the World," in The Evolution of Evil (ed. G. Bennett, J. H. Martinez, T. Peters and J. Russell; Göttingen: Vandenhoeck \& Ruprecht, 2008), 207-208. 
mechanical in most instances, it did evolve in some species. "Then caring in the sense of having warm emotions between parent and offspring, evolved. The capacity for something like human love evolved" ${ }^{40}$ The evolution of sex entailed the phenomena of deception and competition: "With the evolution of sex, males compete directly against each other for females... and females competed to some extent for males... With the evolution of the capacity for emotions accompanying caring, concomitant painful emotions also evolved. Jealousy arose as fear of losing out; grief accompanied loss. New pleasures and new pains appeared.... If sex drove intelligence, so did the evolution of carnivores". ${ }^{41}$ Thus one could trace the entire process. An important facet is the role of emotions in mammals, where warmth, closeness, relationship, family ties, gregariousness and anything that promotes or harms it are significant. ${ }^{42}$ All this inevitably evokes emotion, in contrast to cold-blooded reptiles where emotion is absent and fight or flee are the dominant instincts. Damasio puts it aptly: "But one wonders how the world would have evolved if humanity had dawned with a population deprived of the ability to respond toward others with sympathy, attachment, embarrassment, and other social emotions that are known to be present in simple form in some nonhuman species." ${ }^{\prime 3}$ It would have been a society with no care, altruism or religion. Damasio considers it unlikely that humans would ever have devised religious systems without such basic social emotions. ${ }^{44}$

Historically emotions were not always rated positively. Plato rejects emotion, along with art and the theatre that address an emotional appeal. ${ }^{45}$ Hume maintained that reason is the slave of emotion. ${ }^{46}$ Kant mistrusted emotion at any level. Hegel's condemnation of Schleiermacher's emphasis on affect is well known. ${ }^{47}$ In the context of Edwardian and Victorian morality emotions were

\footnotetext{
${ }^{40}$ Williams, "How Evil Entered the World," 210.

${ }^{41}$ Williams, "How Evil Entered the World," 207-211.

${ }^{42}$ Animals often act in a manner that suggests some sort of ethics: "Evidence from birds (such as ravens) and mammals (such as vampire bats, wolves, baboons, and chimpanzees) indicates that other species can behave in what appears, to our sophisticated eyes, as an ethical manner. They exhibit sympathy, attachments, embarrassment, dominant pride, and humble submission. They can censure and recompense certain actions of others. Vampire bats, for example, can detect cheaters among food gatherers in their group and punish them accordingly. Ravens do likewise," Damasio, Looking for Spinoza, 160.

${ }^{43}$ Damasio, Looking for Spinoza, 156.

${ }_{44}$ Damasio, Looking for Spinoza, 158.

45 Stuart Walton, Humanity. An Emotional History (London: Atlantic, 2004), 47, 99, 145, 151.

${ }^{46}$ See Thiselton, Interpreting God, 67.

47 Schleiermacher sees dogma as derived from experience. "Doctrines are accounts of the Christian religious affections set forth in speech," quoted in Thiselton, Interpreting God, 95.
} 
repressed and never displayed. Emotion - especially 'unbridled' emotion - was seen as the animal side of human nature. Humans should control their emotions (as well as their drives and passions) the way a rider reins in her horse. That was probably because emotions were seen as embarrassing and negative. In fact, by and large emotion was considered to make the mind irrational. The Scottish Enlightenment regarded positive, moral emotions like sympathy as part of human behaviour and justified them emotionally. ${ }^{48}$ Spinoza grounded thought in corporeality and was positive about emotionality: "The rationality Spinoza craved required emotion as an engine". ${ }^{49}$ To determine the influence of emotion on rationality, emotionality - like brain processes - have to be approached in a more differentiated manner. ${ }^{50}$

Of the six emotions that Darwin describes in his The Expression of Emotions in Man and Animals (1872) only one is positive (happiness). The other five are negative: sadness; anger; fear; disgust; and surprise. Darwin confined himself to emotions that are directly observable in bodily and facial movements. His six can be augmented with guilt or shame, embarrassment, jealousy and contempt. There are also more peripheral emotions that can be isolated like pride, sympathy, admiration, frustration, nostalgia and the like. And who would deny that love and hatred are emotions, even though they may overlap some of the others?

The question we shall briefly consider is how to accommodate all aspects of human nature that affect our thinking in a bodily culture that has rediscovered our embodied ideas and rationality. How can we accommodate human affect in rationality? ${ }^{31}$ It is like a mystic who ultimately has to verbalise the most ineffable experiences, thus "surrendering" them to language. Must human affect (including values, belief, commitment, wonderment, anger, etc.) remain

\footnotetext{
48 Damasio, Looking for Spinoza, 320, n.23.

49 Damasio, Looking for Spinoza, 227.

50 Damasio, Looking for Spinoza, 43-46, distinguishes between background, primary and social emotions. Background emotions are subtle emotional influences that put us in a particular mood. Primary emotions are basic feelings like fear, anger, disgust, surprise, sadness and joy. They are transcultural. Social emotions include sympathy, embarrassment, shame, guilt, pride, jealousy, envy, gratitude, indignation and contempt.

51 Feeling, like the role of negativity, often does not reach the surface level of language, yet without it we cannot understand language. Jean-Luc Nancy, Hegel. The Restlessness of the Negative (Minneapolis: University of Minnesota Press, 1977), 24-35, puts it aptly: "To penetrate negativity (also read feeling - CWdT) demands 'another language' than the language of representation. The latter is the language of separation: the language of concepts and their fixity, of propositions and their copulas; it is the language of signification... To speak the other language - that of thought - is not to speak a mysterious extra language. But it is above all not to enter the ineffable. It is to think: to say within language what language does not say; to make language say the identity of subject and object..."
} 
isolated from logical systems, rationality and epistemology - or are there ways of accommodating it? Normally we acknowledge that affect influences us, but find it difficult to pinpoint its role. It is also easier to confine the role of emotion and feeling to the moral/ethical, judicial, religious and aesthetic dimensions but to exclude it from our rationality.

No profound experience can be divorced from emotion. Indeed, its profundity lies in its startling novelty which is emotionally charged. These are also our most memorable experiences. Most of us remember where we were the day Mandela was released, when we saw the first screen images of $9 / 11$. What makes us remember an event is the concomitant shock, astonishment, fear, embarrassment, et cetera. That is why Caputo refers to the event in an experience that makes it remarkable. ${ }^{52}$

Emotion is not the same as feeling. Feeling is associated with our mood or state of mind. Emotions precede it, determining our state of mind. Of course, we contribute to our state of mind by consciously deciding to repress emotion or to cultivate positive emotion by viewing an event or circumstance in a different light. Damasio puts it thus: "Feelings are just as mental as the objects or events that trigger the emotions. What makes feelings distinctive as mental phenomena is their particular origin and content, the state of the organism's body, actual or as mapped in body-sensing brain regions." ${ }^{\text {53 }}$ Mood has to do with atmosphere, which is connotatively associated with places, people, events and even words. My childhood home has a certain atmosphere, it is tied up with things like wide open plains or a beautiful spot in nature. That is why we visit spots in nature that move us. They are associated with affect, hence with specific memories. Certain words, phrases or texts convey a particular atmosphere, especially at a religious level. We recall incidents from memory which, on reliving them, affect our mood. Human intuition, too, should probably be viewed in this light - Spinoza saw it as the most sophisticated way of acquiring knowledge. ${ }^{54}$ That is because intuition has its source in experience, conscious or unconscious, and in aspects of it that are stored in our emotional memory the domain of the amygdala. A sensory stimulus will activate the amygdale to obtain input from the neo-cortex, whereupon the hypothalamus sends a message to the adrenal cortex. The latter secretes cortisol, which pushes up blood pressure and glucose levels in the blood, thus enabling us to respond to the stimulus. The remarkable thing is the emotional memories stored by the amygdale. They link memory and emotion, making me act reflexively when my life is in danger or when fear, anger or hatred is aroused.

\footnotetext{
52 Caputo in Caputo and Vattimo, After the Death of God, $47 \mathrm{ff}$.

53 Damasio, Looking for Spinoza, 65.

${ }^{54}$ Damasio, Looking for Spinoza, 274.
} 
Damasio speaks of maps that the body devises in collaboration with the brain to monitor and coordinate all processes. ${ }^{55}$ What this implies is that the entire body is tied up with brain functions, and that the brain responds - consciously or unconsciously - to every impulse. "[T] he mind is built from ideas that are, in one way or another, brain representations of the body... The brain is imbued at the start of life with knowledge regarding how the organism should be managed, namely how the life process should be run and how a variety of events in the external environment should be handled... In brief, the brain brings along innate knowledge and automated know-how, predetermining many ideas of the body". ${ }^{56}$ Hence the complexity of consciousness is composed of the person's external world with all its influences, the mental world with its intentionalities. At any given moment consciousness is also codetermined by the influence of memory, and by the unconscious (inasmuch as it governs consciousness at that moment), as well as all the bodily maps that monitor bodily functions and possible imbalances. All these co-determine consciousness either directly or indirectly under the influence of the lymphatic system and active emotions that govern the person's feelings and state of mind.

Against this background we now return to the question of the influence of affect and rationality on faith. Religion without emotion makes no sense. Love cannot be understood without emotion and is influenced by it. It forms part of the core of Christianity. But because memory, words, places and the like have emotive value, they are not viewed at a rational level. By association some religious places, doctrines, stories and texts convey a certain atmosphere. ${ }^{57}$ When a Bible story, a religious idea like paradise or the devil, angels, creation, miracle story or the story of Jesus's resurrection, which has particular emotive value for a person is denigrated, one would expect protest. That may well be why some believers tenaciously cling to naively realistic religious views. ${ }^{58}$

55 Damasio, Looking for Spinoza, 7, 12.

56 Damasio, Looking for Spinoza, 204-205.

57 With reference to Darwin's view Walton, Humanity, xviii, mentions that "much emotional response derives from the constitution of the nervous system, which, through force of association then governs those responses that derive neither from willed intent not from habit, but are strictly involuntary". It complements emotional habits that can be acquired and the fact that there are sets of emotions that counteract each other.

58 Religion undeniably can have a tremendous emotional hold on people, which must be considered harmful. Here one thinks of fear instilled of punishment, death, demons and powers, judgment, doubt. According to Freudian psychology fear is rooted in Christianity - "in its insistence that all human conduct was subject to bottomless accountability" (10); for more examples, see Walton, Humanity, 131, 134-135, 137. Kierkegaard considers a state of fear and trembling an essential component of faith, Walton, Humanity, 14. For the terror exercised by the medieval church's proclamation of its view of death, see Carlos Eire, A Very Brief History of Eternity (Princeton: Princeton University Press, 2009). 
Maybe it also explains the grassroots popularity of notions about angels, the supernatural, demonic powers, exorcism, crossing-over experiences, communication with departed spirits, Armageddon images and the like. To what extent can reinterpretations of religious ideas be accepted rationally without forfeiting the affective value they once had?

Usually the religious role of emotion is not denied although opinions differ on the way it should be accommodated in liturgy and in practice. Naturally we reject emotionally charged, manipulative religious practice, but we must not throw out the baby with the bath-water: We need to recognise and accommodate an affective dimension in religious rationality, in preaching and religious life generally.

\section{Narrative Accommodation of Human Affect at the Levels of Consciousness, Texts and Real Life}

When I communicate, I convey information - factual knowledge, but also emotions and feelings. When communication is confined to an exchange of information, it somehow remains clinical and mechanical. From a semiological point of view communication is a sign that is sent, interpreted and understood, usually evoking some sort of response. This applies to the most basic communication between organic cells no less that to the most sophisticated human communication at an intellectual level. Fundamentally communication aims at self-preservation, self-defence and defence of significant others, and interaction with the environment. ${ }^{59}$ In the evolution of the human species emotional communication antedates sophisticated lingual communication. Our earliest ancestors relied on one another (and communication with one another) for survival and well-being; individualism did not exist. Some emotions have to be communicated. I am frightened and must communicate in order to get help. I am miserable, I hate, something disgusts me and I need to communicate to be rid of the feeling. Emotions are usually short-lived and can change as a result of other emotions (usually negative ones as a result of more positive ones). But this can only happen through communication. When I'm happy I am bursting to share it with someone and it is actually in sharing it with somebody that the value of being so happy comes into its own. Solitary happiness is an oxymoron - which raises the question whether present-day virtual communication will not make our actions increasingly clinical, devoid

${ }^{59}$ See the autopoietic model in C. W. du Toit, Viewed from the Shoulders of God (Pretoria: RITR, 2007), 208ff. 
of affect and eventually inhuman. ${ }^{60}$ Communication in empirical sciences is not devoid of affect, as evidenced by running down the street shouting 'eureka'.

There are many instances of links between rationality and affect in religious practice, such as prayer, singing, sacraments and various other rituals. Always they entail communion and communication. The critical question is how rationality functions at these levels. Viewed objectively, they are naïve, overly literal rather than critical. ${ }^{61}$ And when the rational content of faith is scrutinised critically, affect is dismissed and relegated to the background. We separate the phase of intensely critical scrutiny from the celebration of truth (once a couple has made up they don't start interrogating each other all over again). Celebration of faith usually follows critical religious scrutiny. Thus it separates critical rational faith from its affective experience. ${ }^{62}$

Yet it is more complex than that. If critical religious scrutiny has changed my views, it will necessarily influence my religious experience and celebration of my faith. We cannot simply suspend our critical faculties, Kantian style, when it comes to practicalities and affect. Hence many consider the price of a critical orientation too heavy, which explains why some believers hang on to fundamental, literal religious contents in their worship. Denying Father Christmas's existence spoils Christmas for ourselves and our children. So, is theological insight a spoil-sport when it comes to religious experience? We can reflect critically and cynically about the hereafter, death and hell, but at the graveside we fall back on naively literal sentiments because they convey our affect most effectively. We are cynical about miracles that conflict with a scientific worldview, but at a child's death bed we pray for a miracle.

Religion cannot be understood at a purely rational, intellectual level. It has always emphasised both heart and mind, reason and emotion. That is one reason for the pre-eminence of narrative ${ }^{63}$ as the medium of affective

\footnotetext{
${ }^{60}$ A student studying abroad building his relationship with his love on daily correspondence may find her married to the mail carrier on his return!

${ }_{61}$ The notion that texts have a deeper 'spiritual' meaning and Origen's method of allegorical exegesis probably stem from the fact that the affective 'load' of the text as it stands is too flimsy and the more emotionally charged deeper or 'actual' meaning is necessary to involve the reader affectively.

${ }^{62}$ Ricoeur puts it beautifully: "The universal function of feeling is to bind together. It connects what knowledge divides; it binds me to things, to beings, to being. Whereas the whole movement of objectification tends to set a world over against me, feeling unites the intentionality, which throws me out of myself, the affection through which I feel myself existing," Paul Ricoeur, Fallible Man (New York: Fordham University Press, 1986), 131.

${ }^{63}$ Ricoeur stressed the importance of narrative for theology. We see our life story as analogous to the technique of novels. See Paul Ricoeur, Oneself as Another (Chicago: University of Chicago Press, 1992), 113-139.
} 
communication, replacing clinically rational models, because stories are better able to accommodate human affect, intentionality and values. ${ }^{64}$ That largely explains the success of Habermas's communicative act. Narrative remains the medium in which we express our experience. ${ }^{65}$

\section{Conclusion}

Post-Reformation theology seeks to apply developments and insights from disciplines like philosophy, biology and linguistics to Reformed thinking in a secular spiritual context. The aim is not to discard the Reformed tradition, but to reinterpret it in light of our present self-understanding and worldview. In regard to the Bible the question is not whether it contains revelation, but the fact that it can engender an experience of transcendence. In a metaphorical, symbolic and narrative sense the Bible is accepted as integral to our religious culture, a text that still offers scope for religious worship, provided we know that we understand, and therefore believe it differently. God is experienced in immanent transcendent mode in an encounter (transcendent event) that illuminates our existence. The metaphysical concept of atonement is reinterpreted to accord with our present-day self-understanding. A literal interpretation of the sin-redemption-gratitude schema does not accommodate the way we experience ourselves today. Desire-event-fulfilment may be a better way of accommodating our self-understanding (and the human condition). Desire is a metaphor for self-understanding in the sense of openness, infinitude and transcendence. Without desire (positive or negative, depending on the context) human existence as we know it is not possible. The future does not entice us, life has no allure and transcendence is inconceivable. That is human existence in Sartre's pour-soi mode (minus the negative connotation of existential philosophy). Salvation as a business transaction concluded on the cross is unworthy of the belief that God is love. How can a God who demands recom-

\footnotetext{
${ }^{64}$ Although theologians try to capture the doctrine of God in rational, metaphysical models, narrative is the natural mode for speaking about God. "We must conclude that the search for God and our talk about God always happens in the context of the stories circulating about him... The being of God is determined on basis of a story - not any random story, but a story that inspires people," Ben Vedder, "The Question into Meaning and the Question of God: A Hermeneutical Approach," in Transcendence in Philosophy and Religion (ed. James E. Faulconer; Bloomington: Indiana University Press, 2003), 48.

${ }^{65}$ It is akin to Sartre's impure reflection (orientation to an object): "It is akin to impure reflection, which also, I think, involves putting what one sees about oneself into language and thus telling oneself (and others) a story about who one is and what one's life means," Wider, The Bodily Nature of Consciousness, 157.
} 
pense excite worship? The life and stories of Jesus attest the opposite! Hence this God strikes us as metaphysical, deistic and culturally alien (the primitive notion of sacrifice). Salvation is not substantively ontological but relational. It is an event, a startling event in human experience - an encounter with transcendence - that gives our humanity new meaning and clarity. Fulfilment is the experience that we can flourish and find happiness in life, but without extinguishing the desire that drives us in our ongoing development.

All this must be seen against the background of our self-understanding and the nature of our corporeally rooted thought and consciousness. Human affect is accommodated in all its dimensions, including the way it determines our rationality, science, perceptions and judgments. That is the framework in which religion comes into its own as a plausible, honest approach that accommodates other faiths, and in which we can recognise ourselves and our human condition.

\section{Bibliography}

Bhaskar, Roy. A Realist Theory of Science. Sussex: Harvester Press, 1978.

Caputo, John D. and Gianni Vattimo. After the Death of God. New York: Columbia University Press, 2007.

Damasio, Antonio. Looking for Spinoza. Joy, Sorrow and the Feeling Brain. Orlando: Harcourt, 2003.

Delanthy, Gerard and Piet Strydom, eds. Philosophies of Social Science. Philadelphia: Open University Press, 2003.

Depoortere, Friedriek. Christ in Postmodern Philosophy. Gianni Vattimo, René Girard and Slavoj Žižek. New York: T\&T Clark, 2008.

Du Toit, C. W. Viewed from the Shoulders of God. Pretoria: RITR, 2007.

. "An Immanent Approach to Death: Theological Implications of a Secular View," HTS 65, no. 3 (2009): 484-491.

Dupré, Louis. Transcendent Selfhood. The Loss and Rediscovery of Inner Life. New York: Seabury, 1976.

Eire, Carlos. A Very Brief History of Eternity. Princeton: Princeton University Press, 2009.

Fry, Christopher M. Sartre and Hegel. The Variations of an Enigma in "L'Etre et le néant". Bonn: Bouvier, 1988.

Fuller, Steve. "The Project of Social Epistemology and the Elusive Problem of Knowledge in Contemporary Society." Pages 428-435 in Philosophy of Social Science. Edited by Gerard Delanthy and Piet Strydom. Philadelphia: Open University Press, 2002.

Girard, René. Things Hidden since the Foundation of the World. London: Athlone, 1987.

Hankiss, Elemér. The Toothpaste of Immortality. Self-constructing in the Consumer Age. Baltimore: John Hopkins University Press, 2006.

Hegel, Georg Wilhelm Friedrich. Encyclopedia of Philosophy. Translated by G. E. Mueller. New York: Philosophical Library, 1959.

. The Consummate Religion. Vol. 3 of Lectures on the Philosophy of Religion. Berkeley: University of California Press, 1985. 
Heidegger, Martin. The Question Concerning Technology and Other Essays. New York: Harper \& Row, 2007.

Nancy, Jean-Luc. Hegel. The Restlessness of the Negative. Minneapolis: University of Minnesota Press, 1977.

Ricoeur, Paul. Fallible Man. New York: Fordham University Press, 1986.

. Oneself as Another. Chicago: University of Chicago Press, 1992.

Robbins, Jeffrey W., ed. After the Death of God. John D. Caputo \& Gianni Vattimo. New York: Columbia University Press, 2007.

Sartre, Jean-Paul. Being and Nothingness. An Essay on Phenomenological Ontology. London: Methuen, 1977.

Taylor, C. "Self-interpreting Animals." Pages 55-86 in Martin Heidegger. Edited by Stephen Mulhall. Oxford: Ashgate, 2006.

Thiselton, Anthony. Interpreting God and the Postmodern Self. Edinburgh: T\&T Clark, 1995.

Vedder, Ben. "The Question into Meaning and the Question of God: A Hermeneutical Approach." Pages 35-52 in Transcendence in Philosophy and Religion. Edited by James E. Faulconer. Bloomington: Indiana University Press, 2003.

Walton, Stuart. Humanity. An Emotional History. London: Atlantic, 2004.

Westphal, Merold. "Whose philosophy? Which religion? Reflections of reason as faith." Pages 13-34 in Transcendence in Philosophy and Religion. Edited by James E. Faulconer. Bloomington: Indiana University Press, 2003.

Wider, Kathleen V. The Bodily Nature of Consciousness. Sartre and Contemporary Philosophy of Mind. Ithaca: Cornell University Press, 1997.

Williams, P. A. "How Evil Entered the World." Pages 204-217 in The Evolution of Evil. Edited by G. Bennett, J. H. Martinez, T. Peters and J. Russell. Göttingen: Vandenhoeck \& Ruprecht, 2008.

Zabala, Satiago, ed. The Future of Religion. Richard Rorty and Gianni Vattimo. New York: Columbia University Press, 2005.

Žižek, Slavoj. The Puppet and the Dwarf. The Perverse Core of Christianity. Cambridge: MIT Press, 2003. 